\title{
Present and future of subsurface biosphere studies in lacustrine sediments through scientific drilling
}

\author{
Daniel Ariztegui · Camille Thomas · Aurèle Vuillemin
}

Received: 18 June 2014 / Accepted: 25 January 2015 / Published online: 5 February 2015

(C) The Author(s) 2015. This article is published with open access at Springerlink.com

\begin{abstract}
Recently, the discovery of active microbial life in deep-sea sediments has triggered a rapid development of the field known as the "deep biosphere." Geomicrobiological investigations in lacustrine basins have also shown a substantial microbial impact on lake sediments similar to that described for the marine record. Although only $30 \%$ of the lake sites drilled by the International Continental Drilling Program (ICDP) have included microbial investigations, these lakes cover a relatively wide range of salinities (from 0.15 to $33.8 \%$ ), $\mathrm{pH}$ (from 6.0 to 9.8) and environmental conditions (from very arid to humid subtropical conditions). Here, we analyze results of very recent ICDP lake sites including subsurface biosphere research from southern Patagonia (Laguna Potrok Aike) to the Levantine area (Dead Sea) as well as the East Anatolian high plateau (Lake Van) and Macedonia (Lake Ohrid). These various settings allow the examination of the impact of contrasting environments on microbial activity and their subsequent role during early diagenesis. Furthermore, they permit the identification of biosignatures of former microbial activity recorded in the sediments as well as investigating the impact of microbes in biogeochemical cycles. One of the general outcomes of these preliminary investigations is data to support the hypothesis that microbes react to climatically driven environmental changes that have a direct impact on their subsurface distribution and diversity. This
\end{abstract}

D. Ariztegui $(\bowtie) \cdot C$. Thomas $\cdot$ A. Vuillemin

Department of Earth Sciences, University of Geneva, rue des Maraichers 13, 1205 Geneva, Switzerland

e-mail: daniel.ariztegui@unige.ch

Present Address:

A. Vuillemin

Section 4.5 Geomicrobiology, Helmholtz Centre Potsdam, GFZ

German Research for Geosciences, 14473 Potsdam, Germany is clear at conspicuous levels associated with well-known climatic periods such as the Medieval Climatic Anomaly or the Little Ice Age. Although more research is needed, this relationship between prevailing microbial assemblages and different climatic settings appears to dominate the lacustrine sites studied until to date.

Keywords Lakes $\cdot$ Microbes $\cdot$ Biosignatures $\cdot$ Genomics

\section{Introduction}

In the past few years, geomicrobiological investigations in the lacustrine subsurface have shown that microbial metabolism, as in their marine counterparts, can have a substantial impact on lake sediments. These impacts include dissolution, alteration and precipitation of minerals and changes in redox conditions (Vaughan and Lloyd 2012). While ocean drilling programs (ODP and IODP) pioneered the study of the "deep biosphere" (e.g., D'Hondt et al. 2002, 2004; Hinrichs and Inagaki 2012; Horsfield et al. 2006; Inagaki 2010; Lever et al. 2013; Lomstein et al. 2012; Røy et al. 2012), lake sediments provide a range of characteristics worth investigating. First, they can represent a wider range of different chemical conditions (e.g., from alkaline to acidic, oxic to anoxic), and these differences can occur in short lateral distances. Secondly, lacustrine sediments can also react very quickly to changing conditions with depth as a result of climatic changes or further input, such as volcanic or seismic events that would trigger dramatic transformations in water chemistry. Additionally, the systematically higher sedimentation rate in the lacustrine realm relative to the oceanic realm allows for tracking microbial populations at high resolution through climatic records. Although this can make interpretations more challenging 
than in the well-investigated marine settings, lake subsurface studies also bear opportunities for new findings.

As an example, sediment surveys have revealed the presence of many groups of microbes in ocean sediments (Fig. 1, blue-labeled branches). Many of the archaeal and bacterial phylogenetic groups quite frequently identified in subseafloor sediments have been similarly recognized in lacustrine environments as well (green labels in Fig. 1; Vuillemin 2013; Thomas et al. 2014). Additionally, and due to the large range of environments available through lake drilling, the subsurface biosphere of lacustrine sediments (red-labeled branches) hosts microbial communities rarely found in ocean sediments (blue-labeled branches).

Presently, there is consensus among scientists about the enormous impact of the deep marine biosphere on global element cycles despite the fact its measureable value remains a matter of controversy (Whitman et al. 1998; Kallmeyer et al. 2012). Microbial activity in the water column of modern lakes is quite well known (Newton et al. 2011 and references herein), but significantly less attention has been paid to the study of microbial-related processes in the sediments of lacustrine basins. Just like in the oceans, the microbial community in the sediment is deeply connected to that of the water column, and a suite of biogeochemical reactions involving these two compartments of the biosphere play critical roles in the carbon cycle. Ideally, photoautotrophy, chemoheterotrophy and lithoautotrophy succeed one another, eventually giving way to specific sedimentary footprints. As in the ocean, Bacteria and Archaea are very active in the water column of lakes, being fundamental actors in carbon cycling (Fig. 2, 1). Photosynthetic cyanobacteria, for example, play a clear role in the precipitation of low Mg-calcite in modern Lake Geneva, Switzerland (Fig. 2, 2). This process is recorded as calcified filaments embedded in extracellular polymeric substance or EPS (Plee et al. 2008). The sources of energy necessary for microbial survival change while moving toward aphotic zones where chemical reactions become critical in their fight for survival (Fig. 2, 3), as shown by colonies of sulfur oxidizer Beggiatoa in the bottom waters of Lake Geneva in front of the city of Lausanne (Switzerland). Less known is the impact of living microbes in the sediments which may
Fig. 1 Phylogenetic tree of the three known domains of life on earth (Archaea, Bacteria and Eukarya) summarizing the most recent discoveries through scientific ocean and continental drilling. Blue and red labels represent archaeal and bacterial phylogenetic groups frequently identified in subsea floor and subfloor lacustrine sediments, respectively. Branches labeled in green correspond to groups identified in both marine and lacustrine environments (modified from Inagaki 2010)

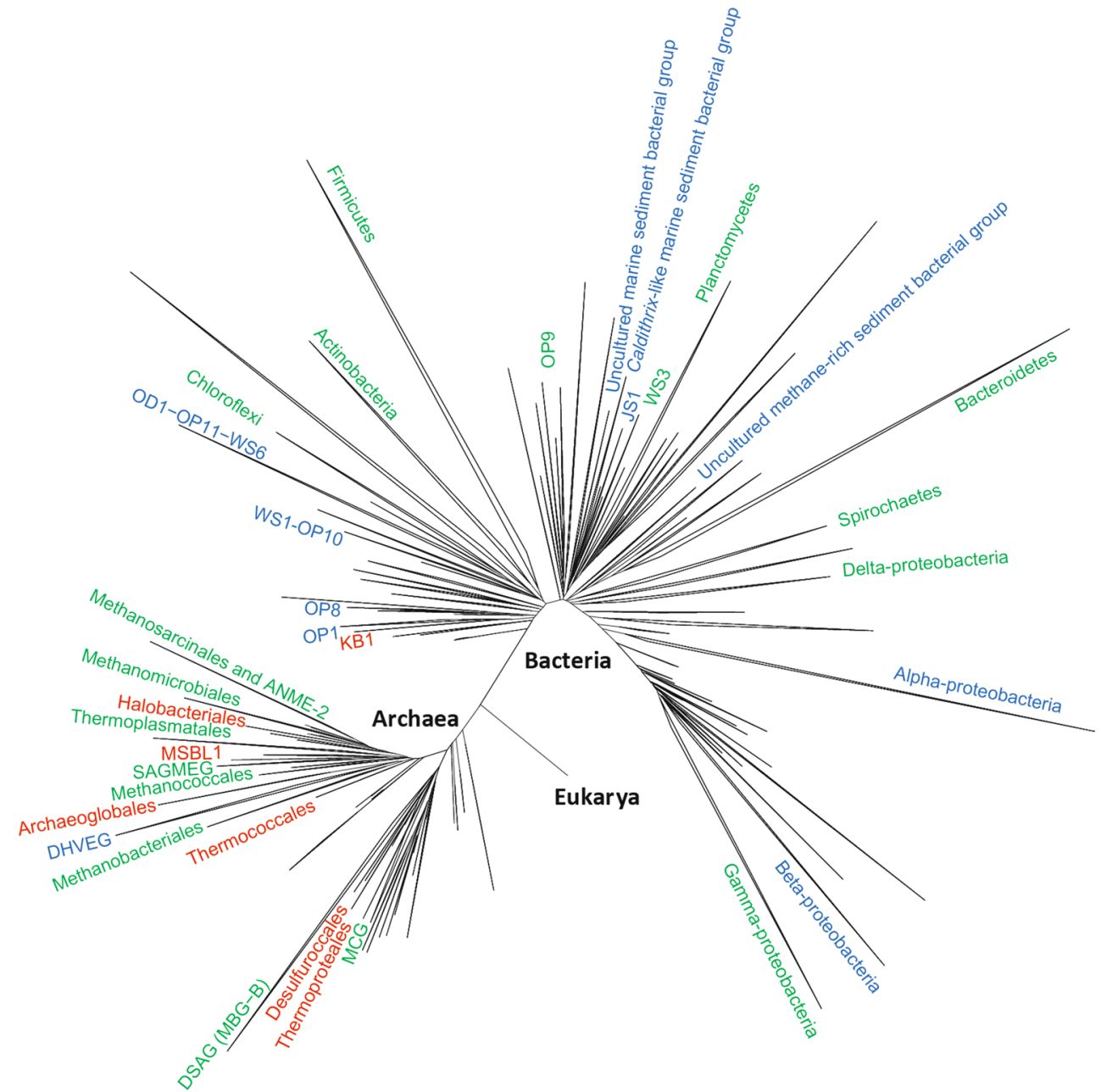




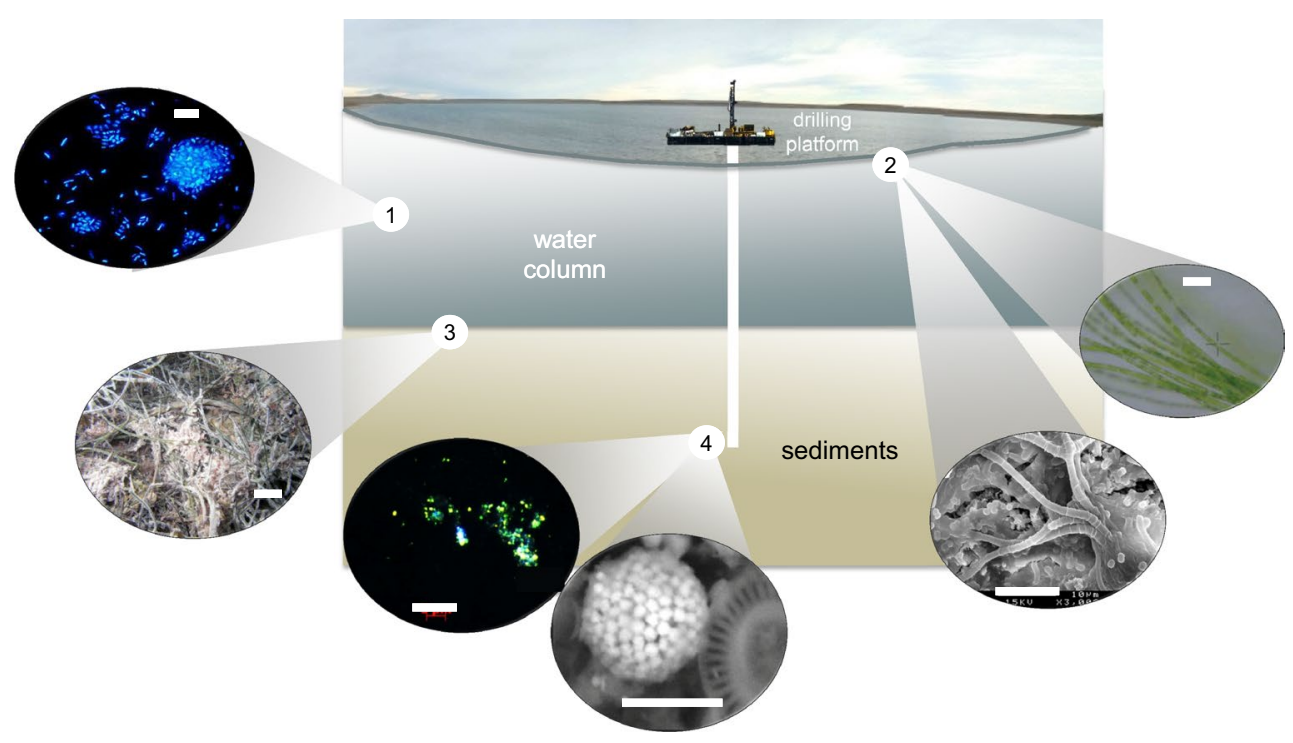

Fig. 2 Drawing of an ideal lake system showing the presence of microbes in different compartments as already identified in several ICDP drilling projects: 1. DAPI (4',6-diamidino-2-phenylindole) microphotograph depicting active microbes in the water column of Lake Grosse Fuchkuhle in Germany; 2. Active photosynthetic microbes under natural light in shallow areas of western Lake Geneva, Switzerland, and SEM microphotographs of carbon-

influence the precipitation of authigenic minerals such as framboidal pyrite (Fig. 2, 4).

The recent development of modern genomics and the emergence of high-throughput gene sequencing technology (e.g., Orsi et al. 2013) have led to a much broader view of the deep biosphere. This eventually led to the concept of the microbiome. Originally coined by Lederberg and McCray (2001) for microbial communities in the human body, it now refers to the entire microbial population within a specific environmental niche. Microbiomes in different environments appear to change in population diversity and density as a function of changes in environmental conditions. When referring to lacustrine sediments, the existing datasets are still limited to fully endorse this statement, but seem to point toward such direction.

Modern lakes represent the largest usable drinking water reservoirs in the world. Despite the fact that interactions between lake water and sedimentary infilling may affect the quality of our drinking water, it was only very recently that subsurface biosphere studies were implemented in ICDP projects (Vuillemin 2013; Vuillemin et al. 2010, 2013a, b, 2014a, b; Glombitza et al. 2013; Thomas et al. 2014). Only $30 \%$ of ICDP lacustrine sites that have been drilled in the last 20 years encompass microbial investigations (Fig. 3). They cover a relatively wide range of salinities (from 0.15 to $33.8 \%$ ), pH (from 6.0 to 9.8 ) and environmental conditions (from very arid to humid subtropical conditions). Here, we present an overview of the scientific results ate precipitates in the same area of the lake (Plee et al. 2008); 3 . Active microbes (Beggiatoa) in the water/sediment interface of Lake Geneva, Switzerland; and 4. FISH (fluorescence in situ hybridization) image of sediments of the Dead Sea showing the presence of active microbes (Thomas, unpublished) and SEM image of framboidal pyrite from sediments of Laguna Potrok Aike, Argentina (modified from Vuillemin et al. 2013a). White bars indicate $10 \mu \mathrm{m}$

already available from these sites (Fig. 3, large gray dots) to provide plausible answers to some fundamental standing questions in the field of geomicrobiology. They include (1) the impact of environmental change on the subsurface biosphere; (2) its influence on paleoenvironmental and paleoclimatical proxies, minerals and hydrocarbon reservoirs; (3) the source, composition and significance of subsurface communities; and (4) the limits of life in the subsurface of lakes under contrasting physicochemical conditions.

Overall, the purpose of this contribution is to increase awareness of the importance of implementing microbial research in future ICDP drilling initiatives. Additionally, we propose a close collaboration with the marine research community to draw upon the much wider experience in sampling and sampling handling already gained during a large number of IODP drilling operations.

\section{Case Studies (in chronological order)}

\section{Laguna Potrok Aike, Argentina}

This subsaline maar lake is located in a volcanic field in the southernmost tip of Patagonia, east of the Andes cordillera at $51^{\circ} 58^{\prime} \mathrm{S}$ and $70^{\circ} 22^{\prime} \mathrm{W}$ (Fig. 3). The lake has been the target of multidisciplinary investigations through continental drilling (Project PASADO: Potrok Aike Lake Sediment Archive Drilling Project; Zolitschka et al. 2013 and 


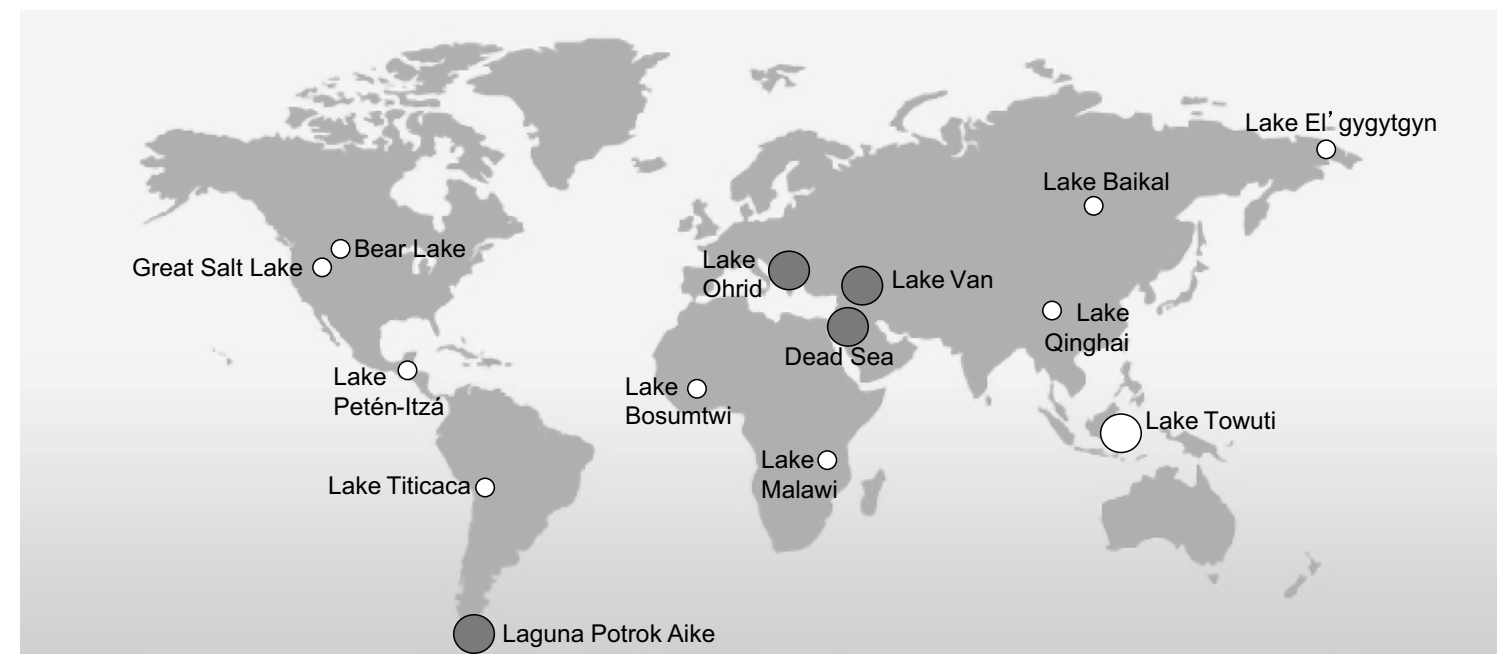

Fig. 3 Map showing already drilled and planned ICDP sites with different levels of subsurface biosphere studies (large dark gray and white dots, respectively). The small white dots indicate sites already drilled without special sampling for subsurface biosphere studies

references therein) and more than $500 \mathrm{~m}$ of sedimentary cores were retrieved. One of the novelties in lacustrine deep drilling was that for the first time in the history of ICDP, a retrieved core was fully dedicated to a detailed geomicrobiological study. A one-meter-long gravity core and a 93-meter-long hydraulic piston core-PTA-5022-1Dwere recovered at $100 \mathrm{~m}$ water depth and sampled following a newly established sampling strategy under aseptic conditions (Vuillemin et al. 2010). Its application has shown that despite the logistical constraints inherent to each project (e.g., absence of appropriate laboratory facilities on board), it is still possible to sample cores aseptically. Using aseptic techniques to sample cores is a key issue for the credibility of the findings for each of the studies reviewed herein.

In contrast to IODP operations, the size and configuration of lake drilling platforms prevent the establishment of a sampling laboratory with minimal conditions of asepsis right at the drilling site. As a result, an ad hoc laboratory was installed in a container on the campsite by the lakeshore and the retrieved cores were transported every $90 \mathrm{~min}$ from the platform to the laboratory. A complete in situ sampling procedure allowed recovering aseptic samples as well as determining the presence of active microbes. Once in the laboratory, the exterior surfaces of the core liners were first disinfected with isopropylic alcohol and sprayed with fungicide. Sampling windows were cut in the liner every 1 or $1 \mathrm{~m}$ and at higher resolution for the upper $15 \mathrm{~m}$ using a portable circular saw. Conversely, windows were cut every $5 \mathrm{~cm}$ in the empty liner of a gravity core and sealed with strong adhesive tape prior to coring. The latter allowed a faster sampling at a higher resolution at the uppermost part of the sedimentary column that encompasses the largest concentration of microbes. The interior surfaces of the core liners were not disinfected prior to coring. However, it is assumed that a contamination by preexisting microbes can be discarded because any potential microbes would have been washed out while descending the drilling tools throughout the water column.

A quick activity test was used to test microbial activity in the sediments immediately after coring. In situ adenosine 5'-triphosphate (ATP) measurements were taken as indication of living organisms within the sediments. The presence of ATP is a marker molecule for living cells since it is not known to form abiotically. ATP can be easily detected with high sensitivity and high specificity using an enzymatic assay because light is emitted as a result of the reaction. The further application of this test to water samples can aid in the evaluation of the degree of contamination of the drilling water, which percolated along the inside of the core liner.

Three and five milliliters of sediment were extracted from freshly opened windows using previously sterilized syringes that had an open-end cutoff in order to use them as minicores. Once the window was cut, the first extracted sample was for methane analyses to prevent it to escape due to volume expansion when exposed to ambient pressure. Hence, $3 \mathrm{ml}$ of sediment was chemically stabilized and sealed in vials for headspace analysis. The sediments were further sampled for different techniques using 5-ml syringes and portioned out as follows: the first 1-ml portion of sample was placed in an Eppendorf tube and kept frozen for further DNA extraction; a second 1-ml portion was chemically fixed for DAPI (4',6-diamidino-2-phenylindole) cell count; a third 1-ml portion of the sediment was mixed with $1 \mathrm{ml}$ of deionized water in an Eppendorf 
Fig. 4 The ICDP drilled Laguna Potrok Aike in southernmost Patagonia, Argentina, has been sampled following a specially tailored approach to allow the first investigation of the subsurface biosphere of this subsaline lake (Vuillemin et al. 2010). The drawings summarize the distinctive depositional environments characterizing the Last Glacial Maximum and Holocene sediments that are reflected in their respective microbial communities (modified from Vuillemin 2013)

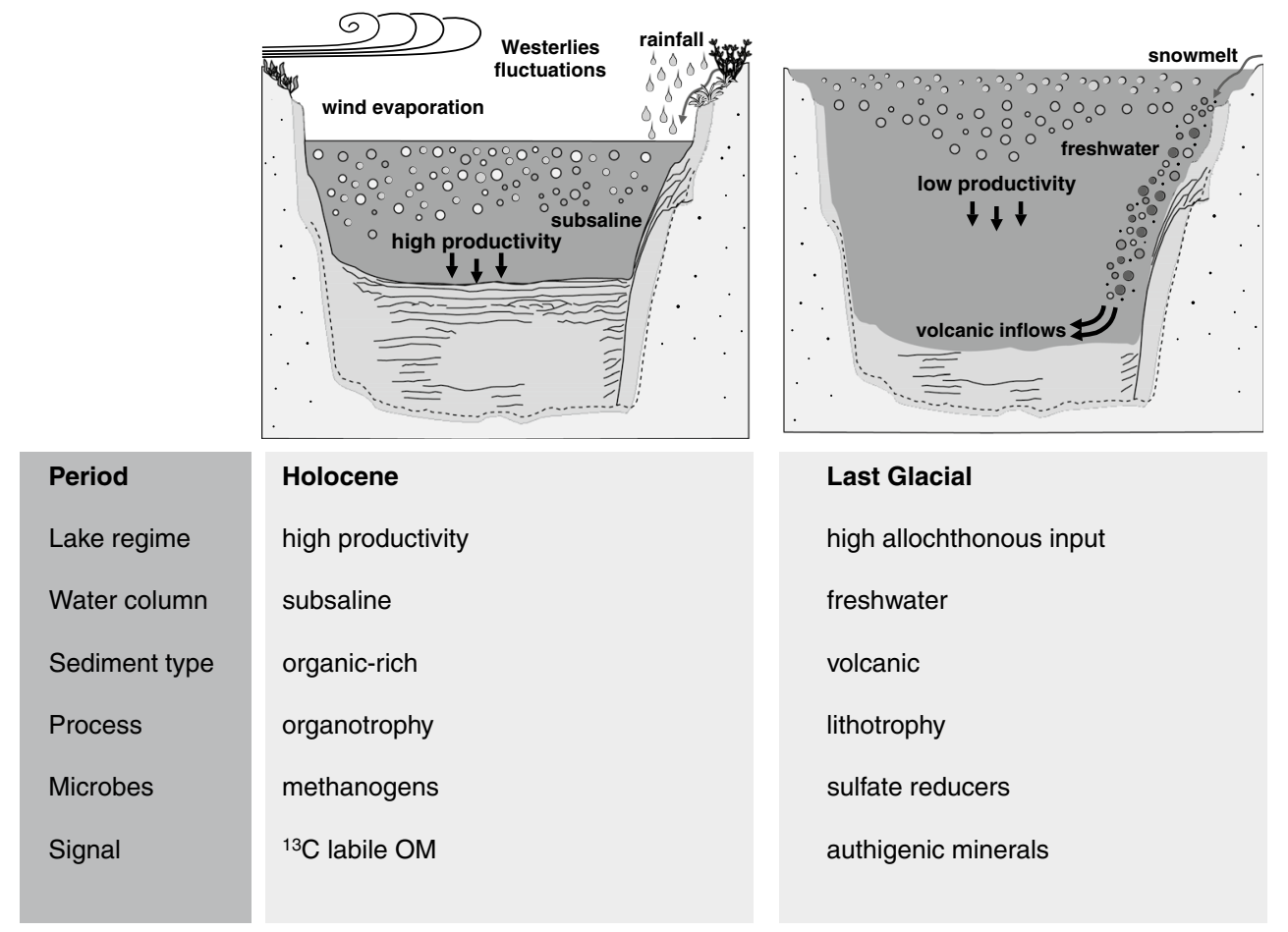

tube and centrifuged for $5 \mathrm{~min}$. Commercially available water testers (Biotrace International) were carefully submerged in the supernatant of the Eppendorf tube, and its ATP content measured with the Uni-Lite ${ }^{\circledR} \mathrm{NG}$ luminometer from Biotrace International as an index of in situ microbial activity. The remnant sediment in the syringe was coated with plastic foil, sealed into hermetic aluminum foil bags and flushed with nitrogen prior to be sealed with a heating device in order to prevent oxidation. These samples can be further used for microbial culture experiments when back at the home laboratory. Once the sampling was accomplished, the windows were sealed with strong adhesive tape. This sampling procedure was carried out nonstop by both day and night shift teams. A more detailed description of the procedures as well as the different methods used can be found in Vuillemin et al. (2010).

The set of cores retrieved in Laguna Potrok Aike covers more than 50,000 years of environmental history of this remote area of the Southern Hemisphere. The multiproxy approach implemented in this research combined with radiocarbon and luminescence dating as well as stratigraphic techniques (tephrochronology and paleomagnetics) provided the opportunity to reconstruct the hydrological history of the region within a well-constrained chronological framework. Lake level was high from 51,000 cal. years BP until the early Holocene when a pronounced negative water balance triggered a lake level decrease of more than $50 \mathrm{~m}$. Lake level started rising gradually two millennia later, reaching a maximum during the Little Ice Age (LIA). These contrasting climatically driven hydrological situations triggered changes in the influx of terrestrial organic matter, sedimentation type, trophic level and productivity. As a result, Vuillemin et al. (2013b) proposed that the structure and sustainability of microbial communities develop in the sediments reflecting the initial depositional conditions (Fig. 4). A detailed geomicrobiological study shows that the shift from an unproductive glacial environment to the more productive Holocene period initiated major and persistent changes in the associated microbial assemblages within sediments (Vuillemin et al. 2014a). Moreover, living microbes have been identified for the first time in sediments from the Holocene (uppermost $10 \mathrm{~m}$ ) and Last Glacial Maximum (LGM; as low as $40 \mathrm{~m}$ depth) periods, providing evidence that environmental DNA can be used to trace paleoclimatic conditions. The comparison of these data with past climate reconstructions indicates that the microbial colonization of the sediment was systematically higher during warmer intervals (Holocene) when the hydrological system was very active (Fig. 4). The concomitant development of high productivity led to enhanced nutrient availability in the sediments, thus sustaining microbial development through organotrophy (Vuillemin et al. 2014b). Conversely, cold intervals, such as glacial times, are characterized by increasing occurrence of mass wasting events preventing the settlement of the same type of microbes but triggering the development of different communities instead. As a result, active microbes were identified at 30,000 cal. years BP in organic poor silts at $\sim 40 \mathrm{~m}$ sediment depth. Despite the low population density, phylogenetic data indicate the presence of 
Fig. 5 Authigenic minerals within sediments can be formed as a result of saturated ion concentrations and/or early diagenetic processes, such as organic matter alteration and microbial activity. Laguna Potrok Aike sediments contain a broad variety of authigenic minerals that are indicative of microbial activity (modified from Vuillemin et al. 2013a)
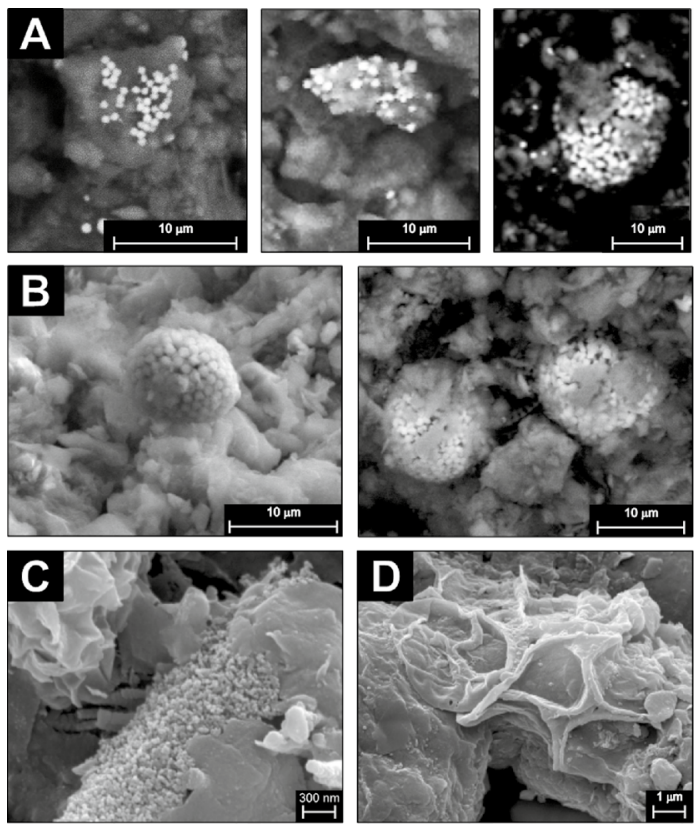
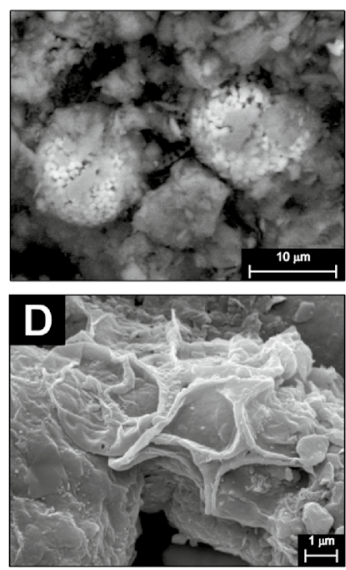

Sequence of formation of framboids(A)

Fully formed framboidsof mackinawite, gregiteand pyrite (B)

Alteration of clays (C) and EPS remnants (D) lithotrophic communities that have caused the formation of authigenic minerals (Vuillemin et al. 2013a). Moreover, these phylogenetic analyses of DNA extracts along with SEM and TEM investigations of selected samples allowed establishing the sequence of formation of framboidal magnetic iron sulfides (mackinawite and gregite) as well as pyrite (Fig. 5a, b). Similarly, the identified microbes can be related to the observed alteration of clays (Fig. 5c) and the presence of EPS remnants at different levels confirming the lithotrophic character of the microbes involved in these processes (Fig. 5d; Vuillemin et al. 2013a).

One of the general outcomes of these pioneer investigations in Laguna Potrok Aike is data to support the hypothesis that microbes react to climatically driven environmental changes that have a direct impact on their subsurface distribution and diversity. This is clear at conspicuous levels associated with well-known climatic periods such as the Medieval Climatic Anomaly (MCA) or the Little Ice Age (LIA). The discrepancy between the in situ microbial activity (ATP) measurements and the total cell counting by DAPI (4',6-diamidino-2-phenylindole) at these levels is reflecting the accumulation of dead microbial cells. This is interpreted as the result of the initial colonization of the substrate by microbes (Vuillemin et al. 2013a, b). It also shows that microbes resolve the scarcity of both nutrients and energy, becoming dominantly lithotrophs or organotrophs in the last glacial and Holocene sediments, respectively. These results are critical to understanding the limits of life in the subsurface of lakes under contrasting physicochemical conditions. On a practical side, this study shows that in the search of biosignatures in the sediments such as diagenetic concretions, it is crucial to use a wide range of high-resolution geochemical and imagery techniques that can be further blended with microbiological results. Only through a careful examination of these two-apparently independent-datasets, it is possible to disentangle the actual role of different microbial metabolisms during early diagenesis.

\section{Lake Van}

Located in the east Anatolian high plateau at 1,648 m above sea level (a.s.l.) in southeast Turkey $\left(38^{\circ} 38^{\prime} \mathrm{N}\right.$ and $42^{\circ} 54^{\prime} \mathrm{E}$; Fig. 3), Lake Van is the fourth largest terminal lake in the world with a salinity of $2.14 \%$ and $\mathrm{pH} 9.81$. The lake stands in a tectonically active area and is surrounded by active volcanoes. These volcanoes provide an excellent means to date the sediments, and the lake sediments themselves contain a unique geological archive of paleoclimate and paleoenvironment covering several glacial-interglacial cycles. The 445-m-deep lake was drilled in summer 2010 as part of the ICDP deep lake drilling project PaleoVan (Litt et al. 2009, 2011; Stockhecke et al. 2014). As previously stated, geomicrobiological studies on deep and large lakes are quite rare, most often due to technical and logistic limitations. However, during this drilling campaign, samples for immediate processing were taken from the core catcher (catching device at the end of each drilling pipe as shown in Fig. 6) for pore water sulfate concentration and microbial turnover rate determination (Glombitza et al. 2013; Kallmeyer et al. this issue). Core catchers were only sampled if the sediments appeared to be clearly undisturbed whole round pieces, which was the case for the majority of the core-catcher material (Glombitza et al. 


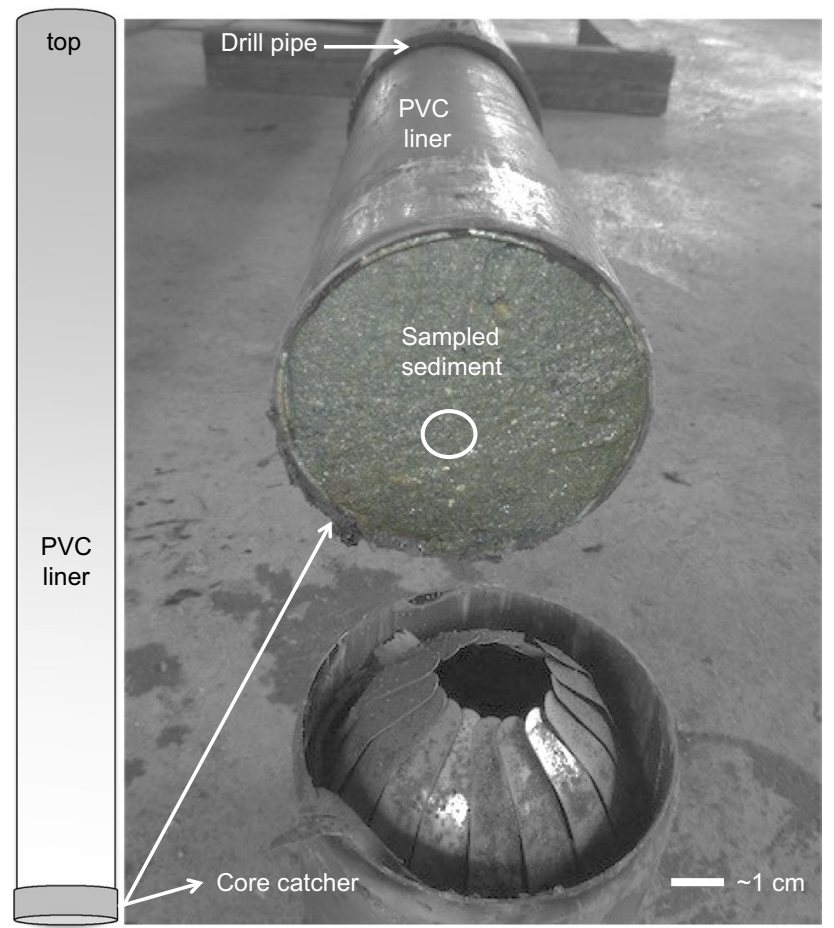

Fig. 6 Photograph showing a liner and an open core catcher on the drilling deck immediately after the core was retrieved. The white circle indicates the sampled section of the sediments. The schema on the left of the photograph illustrates the position of the core catcher at the bottom of the pipe during drilling

2013). Shorter gravity cores (less than a meter long) were also retrieved at the drilled sites to recover undisturbed sediment/water interface. Cores were immediately sampled after retrieval for sedimentary OM characterization, pore water analyses and sulfate reduction rate measurements by radiotracer incubations. Biochemical investigations were carried out in high resolution in the uppermost part of the cores, whereas a $\sim 3-\mathrm{m}$ sampling resolution was acquired down to $130 \mathrm{~m}$ below lake floor. On-site analyses were carried out at the mobile laboratory container BugLab of the Helmholtz Center Potsdam, German Research Center for Geosciences (GFZ). This laboratory is ideal to carry out microbial and geochemical analyses under aseptic conditions. One of the main conclusions of this work is that organotrophs are the dominant microbes at the different drilled sites. It is true as well that the quality of the OM plays a fundamental role for the development of microbial activity and not just the total OM content (Glombitza et al. 2013). As a result, biochemical processes in the sediments of this type of lake basin appear to be very reactive to small variations in geological, physical or chemical parameters even at relatively short lateral distances (Glombitza et al. 2013). This dataset also shows that salinity and alkalinity are not the limiting factors for microbial development. All of these results have substantial implications for the study of early diagenesis in older lacustrine sediments, highlighting the importance of geomicrobiological studies to understand the physiological abilities and biogeochemical impact of subsurface life within the sedimentary column. More results about the subsurface biosphere studies of the long cores retrieved through the ICDP drilling can be found in Kallmeyer et al. (this issue).

\section{Dead Sea}

The present Dead Sea is located at $\sim 425 \mathrm{~m}$ below sea level (b.s.l.) in the Levantine Basin, at the border between Israel, Jordan and the Palestinian Authority. At $31.4^{\circ} \mathrm{N}$, $35.4^{\circ} \mathrm{E}$, the lake lies along the Dead Sea Transform fault system (DST), turning it into a prime target for paleoseismic studies. The site is also ideal to study the impact of climate in the hydrology of the region, to extend the already long record of earthquakes for the area, and to investigate the presence of active microbes that could survive under extreme conditions of salinity (Dead Sea present salinity of $348 \mathrm{~g} \mathrm{~L}^{-1}$ ). ICDP drilling operations started in winter 2010, having retrieved $720 \mathrm{~m}$ of sediment from two different coring sites. Multidisciplinary investigations are currently ongoing, with a strong focus on paleoclimate and paleoseismicity reconstructions (Project DSDDP: Dead Sea Deep Drilling Project; Stein et al. 2011a, b). Based on the correlation of the main lithological units observed in the cores with numerous outcrop studies, down-hole logging and first ${ }^{14} \mathrm{C}$ and U-Th dating, the composite core from the deepest area of the basin is interpreted to encompass the last two glacial-interglacial cycles (Neugebauer et al. 2014).

Within this framework, core catchers from the longest core were prioritized for the geomicrobiology study since, in contrast to Laguna Potrok Aike, no special hole was drilled for subsurface biosphere investigations. In the modern Dead Sea, the microbial content in the water column is very limited, preventing possible contamination of the sampled sediments with water column populations. Additionally, as in the previously described sites, we sampled the center of the individual core catchers (Fig. 6), disregarding their outermost part to minimize the possibility of contamination with drilling water. After each 12-h drilling shift, core catchers were brought onshore to a specially tailored facility for sampling under sterile conditions. Due to its unique salinity characteristics among all other aquatic environments (ten times higher than sea water), the Dead Sea drilling offers the opportunity to address life limits in a unique way. It also allows the assessment of the impact of microbial communities on the sedimentary record of extreme hypersaline environments. 

STRATIFIED LAKE
diluted epilimnion
autotrophy, active degradation of OM
MIXED LAKE
hypersaline water column
extreme halophiles survive, low activity
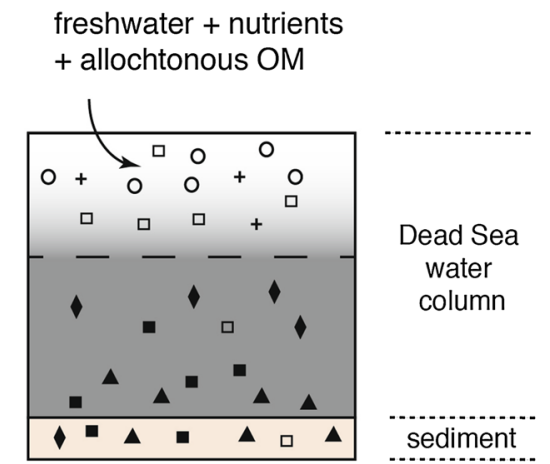

high evaporative rates
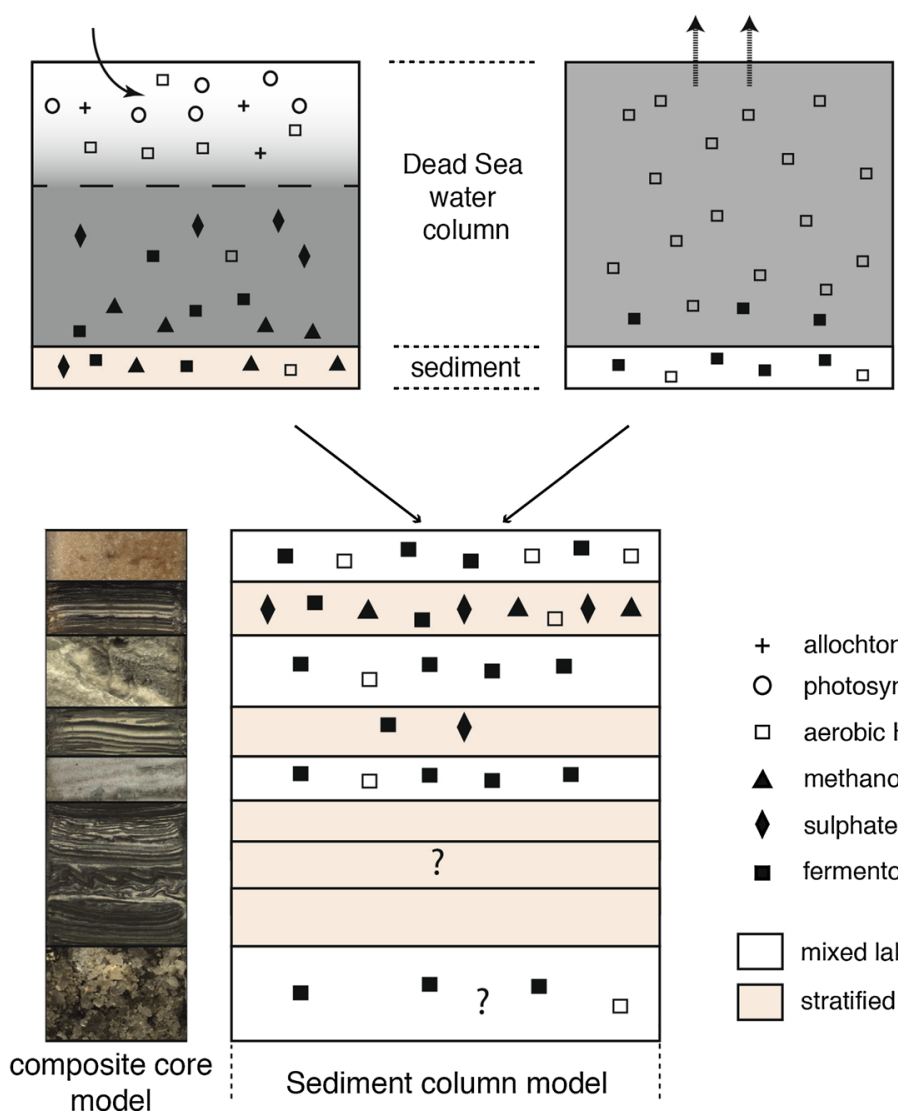

+ allochtonous microbes (not or moderately halophilic)

O photosynthetic halophilic organisms

口 aerobic Halobacteria (Archaea)

$\Delta$ methanogenic Archaea

sulphate reducers

- fermentors (Halobacteria and other halophilic species)

mixed lake sediment halite/gypsum

stratified lake sediment alternating aragonite and detritus

Fig. 7 A close relationship has been observed between prevalent environmentally dependent conditions in the Dead Sea water column and dominant microbial populations identified in the corresponding sediments. Refer to text for explanations

While the chemistry of the Dead Sea sediments challenged the use of several routine methods for the assessment of microbial diversity and in situ activity, DNA extraction has revealed the existence of microbes down to $90 \mathrm{~m}$ below the lake floor (Thomas et al. 2014). Ongoing analyses further point toward their presence as deep as $200 \mathrm{~m}$. The simultaneous analysis of sedimentary facies and microbial assemblages has allowed the identification of mutual patterns in the distribution of these subsurface communities adapted to extreme salinity conditions (348 $\mathrm{g} \mathrm{L}^{-1}$ ). Halophilic species from the Bacteria and Archaea domains display differential distribution regarding the lithology from which they have been extracted. As in the case of Laguna Potrok Aike, these lithologies derive from the climatic conditions prevailing in the Dead Sea Basin at the time of sedimentation. Under humid conditions largely prevalent during glacial periods, the lake precipitated aragonite-forming varve-like sediments. This facies is named aragonite laminae alternating with detrital mud (aad facies). High freshwater inputs diluted the upper layer of the lake and subsequently formed a stratification of the water column. The nutrient-rich, diluted epilimnion was subjected to algal blooming events and subsequent aerobic degradation by microbial halophilic species (Fig. 7). Other transported-allochthonous-microbes potentially developed in these moderately saline conditions. In such settings, the Dead Sea hypersaline brine was restricted to the hypolimnion. This situation rapidly enabled anoxic hosting halophiles to degrade organic matter anaerobically. Resulting organic matter was buried and potentially degraded by fermenters, sulfate reducers and methanogens as revealed by metagenomes from the aragonitic sediment (Thomas et al. 2014). Under the more arid conditions prevailing during interglacials, the lake became monomictic and oxic conditions predominated in the entire water column. Evaporation exceeded precipitation, and the lake started 
to precipitate gypsum and, eventually, halite (as observed today). Hypersaline conditions only allow for Archaea of the Halobacteria class to survive in the water column (Bodaker et al. 2010). This very same class largely dominates in the corresponding sediment (Thomas et al. 2014). Consequently, this first dataset indicates that conditions existing in the water column at the time of sedimentation influence microbes preserved in the Dead Sea sediment. This is illustrated in the idealized sketch shown in Fig. 7.

These preliminary results indicate that the Dead Sea subsurface microbial community does not depend only on salinity. Although halophilic species are the dominant form obtained from sequencing techniques, Archaea of the Halobacteria class predominate within halite-gypsum sediments, while sequences related to hypersaline methanogens and fermenters are found in the shallowest aad facies. Thus, as in Laguna Potrok Aike, the sedimentary microbial communities in the Dead Sea seem to reflect the conditions in the water column at the time of sedimentation, linking their distribution to the prevailing climate. Additional investigations are necessary to better understand the microbial origin and evolution through time. Analogously, the traces of activity left by these microbes on the sediment are complex and not fully yet understood. However, Fe-S mineralization has been observed associated with EPS in some aragoniticrich sediments, showing that even under extremely saline conditions, microbes can affect their environment (Thomas et al. 2014).

\section{Lake Ohrid}

This lake is located between Albania and Macedonia on the Balkan Peninsula $\left(41.1^{\circ} \mathrm{N}\right.$ and $\left.20.8^{\circ} \mathrm{E}\right)$ at an altitude of $639 \mathrm{~m}$ above sea level (a.s.l.; Fig. 3). It is considered the oldest lake in continuous existence in Europe containing more than 200 endemic species (Wagner et al. 2014 and references herein; Wilke et al. 2010), which makes it a particularly interesting place to investigate the subsurface biosphere. It was successfully drilled in spring 2013. Although there were neither a planned geomicrobiological study nor cores specially retrieved for this purpose, a core-catcher sampling was implemented in the deepest site following the precautions mentioned for previous drilling projects. Samples were immediately frozen for subsequent studies. While this sampling is not ideal for in situ microbial activity investigation or incubation studies, immediately frozen samples are perfect for certain biogeochemistry and geomicrobiological investigations, such as biomarker analyses, DNA extraction and subsequent microbial ecology techniques (PCR and sequencing) studies. Ongoing analyses have allowed the extraction of DNA down to $134 \mathrm{~m}$ sediment depth. Hence, they may deliver a first view of the subsurface microbial activity and its genetic continuity in this unique site characterized by a large number of endemic eukaryote species.

\section{The way ahead}

At present, there is a limited number of subsurface microbial studies in lacustrine settings. Despite this scarcity, the results of the first geomicrobiological investigations in ICDP scientific drilling sites are quite promising. It already provides critical information to answer some open questions dealing with the impact of active microbes in the sediments. Laguna Potrok Aike, so far the best-studied lacustrine site for this purpose, has delivered some interesting conclusions. As for the Dead Sea and Lake Van sediments, it appears that the initial environmental conditions prevailing in the water column of these lakes affected both the composition and distribution of the microbial mass, which in some cases, have remained active within the sediments. A comparison between contrasting climatic zones derived from paleoclimatic proxies and microbial units derived from cluster analyses of geomicrobiological proxies in Patagonian lake Potrok Aike (Vuillemin et al. 2013b) provides an excellent approach to investigate the influence of different paleoenvironments on the distribution of microbial communities. It also appears that salinity and alkalinity are not the limiting factors controlling microbial development and survival because active microbes have been detected as deep as $200 \mathrm{~m}$ below the lake floor in the Dead Sea sediments, one of the saltiest water bodies in the world. In their fight for survival, microbes can be fueled using sedimentary organic matter and/or mineral matter depending on that resource's availability in the environment. As a result, the development and distribution of conspicuous microbial communities can reasonably be related to former climatically driven environmental changes. A rigorous statistical treatment of coupled geomicrobiological and paleoenvironmental proxies is critical to confirm or dismiss this correlation.

Several diagenetic processes directly associated with microbes have been identified, in particular the formation of authigenic minerals that can be used as biosignatures of past microbial activity in the geological record. The study of these minerals, coupled with modern phylogenetic techniques and pore water analyses, is critical in determining the exact role of microbial metabolism in the complex reactions leading to their development. With the emergence of high-throughput gene sequencing technology, microbes can be grouped in microbiomes that in the sedimentary realm are best defined as microbial facies. As with lithological types, these microbial facies are representative of a given depositional environment. With regard to lacustrine sediments, existing data necessary to fully establish a 
relationship between climate and microbial facies remain limited and require further study.

The significance and validity of the results of these types of investigations are largely dependent on the quality, rapidity and prevailing conditions during the initial sampling. Closer collaboration with the marine research community will enable standardization of sampling methods. Through this collaboration, the lake community could benefit from the various experiences in sampling and sample handling already gained during a large number of IODP operations. Such methodological coordination will allow (1) reduction in the impact of contamination, (2) determination of the best method(s) to accomplish onsite cell counting, in situ microbial activity and substrate turnover rate measurements, (3) selection of the appropriate sampling protocol for further molecular characterization and (4) standardization of sample archival. Due to the different nature of each drilling project, the need for standardized biological sampling, processing and analysis is quite significant. New ICDP sites such as Lake Towuti in Indonesia (Russell et al. 2014) incorporate and implement an appropriate sampling strategy for subsurface studies from the initial phase of the project.

As in the marine realm, the main challenge for the development of subsurface biosphere studies in lacustrine settings is to obtain intellectual reciprocity from other scientific disciplines participating in ICDP drilling initiatives. It is important for future ICDP projects in the terrestrial realm to involve geomicrobiologists in discussions about the effects of an active biosphere on the subsurface environment. Paleoenvironmental reconstructions largely depend on the use of proxies that need to be fully understood because this is crucial in any attempt to reconstruct past environmental changes. Many of these proxies are based on organic compounds (biomarkers) and inorganic constituents, including stable isotope compositions. Thus, a clear understanding of the impact of different microbial communities on proxies is vital.

Acknowledgments The authors are thankful to all participants of the PASADO and DSDDP projects for their help and patience with field and laboratory sampling. AV and DA are particularly thankful to the PIs and research team of the PASADO project for devoting an entire core for this pioneer study. We kindly acknowledge the J. Pawlowski team (Department of Genetics and Evolution, University of Geneva) for their assistance and advice on different microbiology methods. CT and DA thank D. Ionescu from MPI Bremen, Germany, for his help and for sharing his knowledge of the Dead Sea microbiology. DA kindly acknowledges discussions and suggestions from H. Mills, J. de Leeuw and the team of the Advancing Subsurface Biosphere and Paleoclimate Research Workshop (ECORD/ICDP Magellan Plus Workshop Series Program). C. Glombitza and an anonymous reviewer along with associated editor L. Soreghan are thanked for constructive comments that improved the original manuscript. This research has been possible through the combination of multiple funding agencies including ICDP and all partners from the different drilling projects; generous funding from the Swiss National Science Foundation (Grants 200020119931/2-PASADO - and Projects 200021-132529 and 200020$149221 / 1$-DSDDP) to DA; and the University of Geneva, Switzerland.

Open Access This article is distributed under the terms of the Creative Commons Attribution License which permits any use, distribution, and reproduction in any medium, provided the original author(s) and the source are credited.

\section{References}

Bodaker I, Sharon I, Suzuki MT et al (2010) Comparative community genomics in the Dead Sea: an increasingly extreme environment. ISME J 4:399-407. doi:10.1038/ismej.2009.141

D'Hondt S, Rutherford S, Spivack AJ (2002) Metabolic activity of subsurface life in deep-sea sediments. Science 295:2067-2070

D’Hondt S, Jørgensen BB, Miller DJ et al (2004) Distributions of microbial activities in deep subseafloor sediments. Science 306:2216-2221

Glombitza C, Stockhecke M, Schubert CJ, Vetter A, Kallmeyer J (2013) Sulfate reduction controlled by organic matter availability in deep sediment cores from the saline, alkaline Lake Van (Eastern Anatolia, Turkey). Front Microbiol 4:209. doi:10.3389/ fmicb.2013.00209

Hinrichs K-U, Inagaki F (2012) Downsizing the deep biosphere. Science 308:204-205

Horsfield B, Schenk HJ, Zink K, Ondrak R, Dieckmann V, Kallmeyer J, Mangelsdorf K, di Primio R, Wilkes H, Parkes RJ, Fry J, Cragg B (2006) Living microbial ecosystems within the active zone of catagenesis: implications for feeding the deep biosphere. Earth Planet Sci Lett 246:55-69

Inagaki F (2010) Deep subseafloor microbial communities. In: Encyclopedia of life sciences. Wiley, Chichester. doi:10.1002/9780470015902.a0021894

Kallmeyer J, Pockalny R, Adhikari RR, Smith DC, D'Hondt S (2012) Global distribution of microbial abundance and biomass in subseafloor sediment. Proc Natl Acad Sci USA 109:16213-16216

Lederberg J, McCray AT (2001) Ome sweet 'omics—a genealogical treasury of words. Scientist 15:8-10

Lever MA, Rouxel O, Alt JC et al (2013) Evidence for microbial carbon and sulfur cycling in deeply buried ridge flank basalt. Science 339:1305-1308

Litt T, Krastel S, Sturm M, Kipfer R et al (2009) "PALEOVAN", international continental scientific drilling program (ICDP): site survey, results and perspectives. Quat Sci Rev 28:1555-1567. doi:10.1016/j.quascirev.2009.03.002

Litt T, Anselmetti FS, Cagatay MN et al (2011) A 500,000-year-longsediment archive drilled in eastern Anatolia. EOS Trans Am Geophys Union 92:477-479. doi:10.1029/2011EO510002

Lomstein BA, Langerhuus AT, D’Hondt S, Jørgensen BB, Spivack AJ (2012) Endospore abundance, microbial growth and necromass turnover in deep sub-seafloor sediment. Nature 484:101-104

Neugebauer I, Brauer A, Schwab M et al (2014) Lithology of the long sediment record recovered by the ICDP Dead Sea Deep Drilling Project (DSDDP). Quat Sci Rev 102:149-165

Newton RJ, Jones SE, Eiler A, McMahon KD, Bertilsson S (2011) A guide to the natural history of freshwater lake bacteria. Microbiol Mol Biol Rev 75(1):14-49

Orsi WD, Edgcomb VP, Christman GD, Biddle JF (2013) Gene expression in the deep biosphere. Nature 499:205-208. doi:10.1038/ nature 12230

Plee K, Ariztegui D, Martini R, Davaud E (2008) Unraveling the microbial role in ooid formation: results of an in situ experiment in modern freshwater Lake Geneva (Switzerland). Geobiology 6:341-350. doi:10.1111/j.1472-4669.2007.00140.x 
Røy H, Kallmeyer J, Adhikari RR, Pockalny R, Jørgensen BB, D'Hondt S (2012) Aerobic microbial respiration in 86-million-year-old deep-sea red clay. Science 336(6083):922-925. doi:10.1126/science. 1219424

Russell JM, Vogel H, Konecky B, Bijaksana S, Huang Y, Melles M, Wattrus N, Costa K, King JW (2014) Glacial forcing of central indonesian hydroclimate since 60,000 years BP. Proc Natl Acad Sci. doi:10.1073/pnas.1402373111

Stein M, Goldstein S, Agnon A, Ariztegui D, Brauer A, Haug G, Ito E, Yasuda Y (2011a) Deep drilling at the Dead Sea. Sci Dril 11:4647. doi:10.2204/iodp.sd.11.04.2011

Stein M, Ben-Avraham Z, Goldstein S, DSDDP Science Team (2011b) Dead Sea deep cores: a window into past climate and seismicity. EOS Trans Am Geophys Union 92(49):453-464

Stockhecke M, Sturm M, Brunner I et al (2014) Sedimentary evolution and environmental history of Lake Van (Turkey) over the past 600,000 years. Sedimentology 61(6):1830-1861. doi:10.1111/ sed. 12118

Thomas C, Ionescu D, Ariztegui D, DSDDP Scientific Team (2014) Archaeal populations in two distinct sedimentary facies of the subsurface of the Dead Sea. Mar Genomics 17:53-62. doi:10.1016/j.margen.2014.09.001

Vaughan DJ, Lloyd JR (2012) Mineral-organic-microbe interfacial chemistry. In: Knoll AH, Canfield DE, Konhauser KO (eds) Fundamentals of geobiology, 1st edn. Blackwell, Oxford, UK, pp 131-149

Vuillemin A (2013) Characterizing the subsurface biosphere in laguna potrok aike sediments (Argentina): a case study. Terre Environ 119:153p. ISBN978-2-940472-20-8

Vuillemin A, Ariztegui D, Vasconcelos C, PASADO Scientific Drilling Party (2010) Establishing sampling procedures in lake cores for subsurface biosphere studies: assessing in situ microbial activity. Sci Drill 10:35-39. doi:10.2204/iodp.sd.10.04.2010
Vuillemin A, Ariztegui D, De Coninck A, Lücke A, Mayr C, Schubert C, PASADO Scientific Team (2013a) Origin and significance of diagenetic concretions in sediments of Laguna Potrok Aike, southern Argentina. J Paleolimnol 50:275-291. doi:10.1007/ s10933-013-9723-9

Vuillemin A, Ariztegui D, PASADO Scientific Team (2013b) Geomicrobiological investigations in subsaline maar lake sediments over the last 1,500 years. Quat Sci Rev 71:119-130. doi:10.1016/j. quascirev.2012.04.011

Vuillemin A, Ariztegui D, Nobbe G, Schubert C, PASADO Scientific Team (2014a) Influence of methano genic populations in Holocene lacustrine sediments revealed by clone libraries and fatty acid biogeochemistry. Geomicrobiol J 31(4):285-298. doi:10.10 80/01490451.2013.824050

Vuillemin A, Ariztegui D, Lücke A, Mayr C, PASADO Scientific Team (2014b) Paleoenvironmental conditions define current sustainability of microbial populations in Laguna Potrok Aike sediments, Argentina. Aquat Sci 76:101-114

Wagner B, Wilke T, Krastel S et al (2014) The SCOPSCO drilling project recovers more than 1.2 million years of history from Lake Ohrid. Sci Drill 17:19-29. doi:10.5194/sd-17-19-2014

Whitman WB, Coleman DC, Wiebe WJ (1998) Prokaryotes: the unseen majority. Proc Natl Acad Sci USA 95:6578-6583

Wilke T, Schultheiss R, Albrecht C, Bornmann N, Trajanovski S, Kevrekidis T (2010) Native Dreissena freshwater mussels in the Balkans: in and out of ancient lakes. Biogeosciences 7:3051-3061

Zolitschka B, Anselmetti FS, Ariztegui D et al (2013) Environment and climate of the last 51,000 years-new insights from the Potrok Aike maar lake Sediment Archive Drilling project (PASADO). Quat Sci Rev 71:1-12. doi:10.1016/j.quascirev.2012.11.024 